University of Nebraska - Lincoln

DigitalCommons@University of Nebraska - Lincoln

Faculty Publications from the Harold W. Manter Laboratory of Parasitology

$12-1973$

\title{
Heligmosomoides johnsoni sp. nov. (Nematoda: Heligmosomatidae) from the Heather Vole, Phenacomys intermedius Merriam
}

Virginia R. Rausch

Arctic Health Research Center

Robert L. Rausch

Arctic Health Research Center, rausch@u.washington.edu

Follow this and additional works at: https://digitalcommons.unl.edu/parasitologyfacpubs

Part of the Parasitology Commons

Rausch, Virginia R. and Rausch, Robert L., "Heligmosomoides johnsoni sp. nov. (Nematoda: Heligmosomatidae) from the Heather Vole, Phenacomys intermedius Merriam" (1973). Faculty Publications from the Harold W. Manter Laboratory of Parasitology. 530.

https://digitalcommons.unl.edu/parasitologyfacpubs/530

This Article is brought to you for free and open access by the Parasitology, Harold W. Manter Laboratory of at DigitalCommons@University of Nebraska - Lincoln. It has been accepted for inclusion in Faculty Publications from the Harold W. Manter Laboratory of Parasitology by an authorized administrator of DigitalCommons@University of Nebraska - Lincoln. 


\title{
Heligmosomoides johnsoni sp. nov. (Nematoda: Heligmosomatidae) from the heather vole, Phenacomys intermedius Merriam
}

\author{
R. L. Rausch and V. R. Rausch \\ Arctic Health Research Center, U.S. Public Health Service, Fairbanks, Alaska \\ Received May 22, 1973
}

\begin{abstract}
RausCh, R. L., and V. R. RausCh. 1973. Heligmosomoides johnsoni sp. nov. (Nematoda: Heligmosomatidae) from the heather vole, Phenacomys intermedius Merriam. Can. J. Zool. 51: 1243-1247. Heligmosomoides johnsoni sp. nov. is described from the cecum of the heather vole, Phenacomys intermedius Merriam, from the Olympic Mountains, Washington. The absence of longitudinal cuticular ridges dorsally separates $H$. johnsoni from species of Heligmosomoides other than $H$. hudsoni (Cameron, 1937), which occurs in varying lemmings, Dicrostonyx spp., and from which $H$. johnsoni is distinguished by its longer spicules, form of the dorsal ray, and other characters. Both Phenacomys and Dicrostonvx have a specialized cecum, with long villi around which the nematodes are found tightly coiled. The zoogeography of heligmosomid nematodes in Phenacomys is briefly discussed.

Rausch, R. L., et V. R. Rausch. 1973. Heligmosomoides johnsoni sp. nov. (Nematoda: Heligmosomatidae) from the heather vole, Phenacomys intermedius Merriam. Can. J. Zool. 51: 1243-1247.

On décrit Heligmosomoides johnsoni sp. nov. parasite du caecum du rongeur néarctique, Phenacomy:s intermedius Merriam, des Montagnes Olympiques de Washington. L'absence de crêtes cuticulaires sur la face dorsale sépare $H$. johnsoni des autres Heligmosomoides à l'exception d' $H$. hudsoni (Cameron, 1937) qui se trouve chez Dicrostonyx spp., et duquel $H$. johnsoni se distingue par ses spicules plus longs, par la forme différente de la côte dorsale et par d'autres caractères. Phenacomys et Dicrostonyx ont un caecum spécialisé, muni de villosités allongées, autour desquelles les nématodes s'enroulent étroitement. La zoogéographie des nématodes héligmosomes chez Phenacomys est discutée.
\end{abstract}

Nematodes of the genus Heligmosomoides Hall, 1916 are parasites of rodents, characteristically inhabiting the small intestine. Among their hosts, the two arvicoline genera, Dicrostonyx and Phenacomys, are distinguished by the presence in the cecum of numerous, long villi. Heligmosomoides hudsoni (Cameron, 1937), known only from varying lemmings, Dicrostonyx spp., occurs in the cecum, coiled tightly around the long villi. Similarly localized nematodes were found in the cecum of a heather vole, Phenacomys intermedius Merriam, by Dr. Murray L. Johnson, Puget Sound Museum of Natural History, University of Puget Sound, who kindly provided the material for study. These nematodes represented an undescribed species of Heligmosomoides.

\section{Materials and Methods}

The skinned carcass of the infected animal, with viscera in situ, had been preserved in alcohol. The nematodes were removed and cleared by evaporation of $70 \%$ ethanol containing $5 \%$ glycerin, after which some were stained in rose bengal in glycerin. The arrangement of the cuticular structures was determined from transverse sections of cleared nematodes. Nematodes in situ were dehydrated in ethanol, embedded by the paraffin method, cut at 0.010 $\mathrm{mm}$, and stained in hematoxylin-eosin.

\section{Results}

The nematodes, red when alive, were coiled sinistrally around the villi, forming six or seven loops, and becoming partially embedded in the mucosa as the strangulated villi increased in diameter. The following description is based upon seven males and seven females. Measurements are in millimeters, with averages (av) in parentheses.

Heligmosomoides johnsoni SP. NOV.

(Figs. 1-6)

MALE: Length 6.2 to 7.1 (av 6.5). Maximum diameter, at level about three-fifths of length from anterior extremity, 0.200 to $0.235(0.210)$. Width at anterior end, 0.032 to $0.040(0.035)$. Width at base of oesophagus, 0.115 to 0.156 (0.130); at level just anterior to bursa, 0.114 to $0.157(0.139)$. Cephalic inflation about 0.098 by 0.055 . Excretory pore 0.332 to $0.405(0.368)$ and nerve ring 0.194 to $0.205(0.200)$ from anterior extremity. Distance from nerve ring to excretory pore 0.137 to $0.162(0.149)$. Cuticle about 0.003 thick, provided ventrally with 11 or 12 longitudinal ridges, 0.0016 to $0.0032 \mathrm{high}$, and decreasing in height dorsad. Oesophagus 0.583 to $0.641(0.613)$ long and 0.053 to $0.060(0.057)$ wide at base. Spicules subequal, 2.21 to 2.46 (2.36) long, with attenuated, slender tips; each consisting of two cylindrical processes discernible in cross section. Bursa slightly asymmetrical, with dextral lobe larger, 0.300 to $0.560(0.424)$ long by 

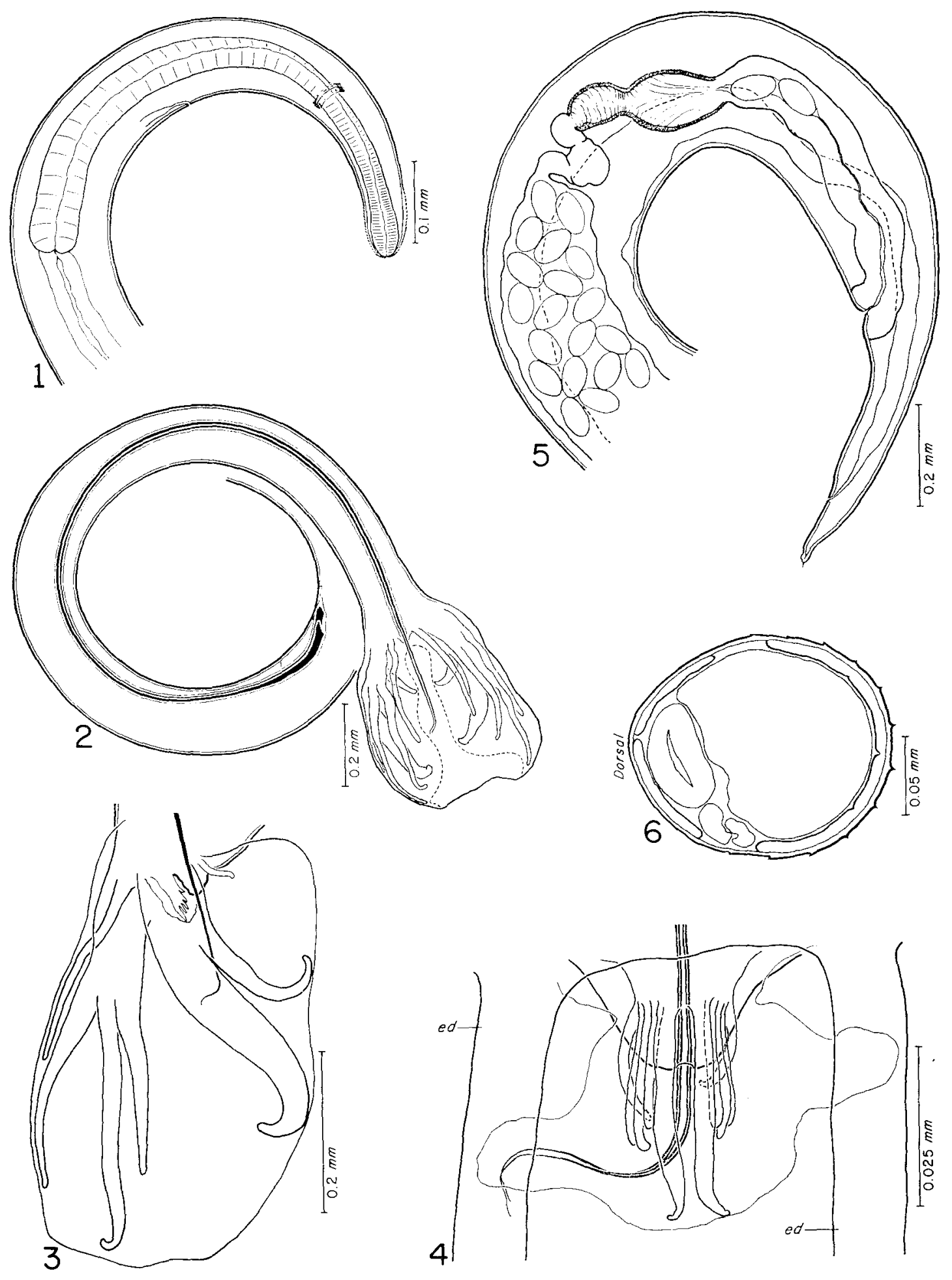
0.259 to $0.400(0.308)$. One pair of prebursal papillae, 0.032 to 0.048 long, present ventrally (see Fig. 3). Genital cone well developed. Dorsal ray complex, having five slender projections bilaterally, of which medial pair is about 0.035 long; four lateral pairs shorter, and nearly uniform in length. Slender externodorsal rays 0.154 to $0.250(0.202)$ long. Common trunk of lateral rays short. Anterolateral rays 0.186 to 0.288 (0.236), mediolateral rays 0.235 to $0.389(0.320)$, and posterolateral rays 0.235 to $0.356(0.299)$ in length. Anteroventral rays 0.130 to $0.280(0.215)$ long; thick posteroventral rays 0.211 to 0.320 (0.302) long. Bursal membrane well developed.

FEMALE: Length 8.2 to 17.7 (av 11.9). Maximum diameter, at level about three-fifths of length from anterior extremity, 0.250 to 0.286 (0.264). Width at anterior end, 0.040 to 0.055 (0.048). Width at level of nerve ring, 0.102 to $0.108(0.105)$; at base of oesophagus, 0.138 to $0.214(0.164)$; at level of vulva, 0.121 to 0.157 (0.137); at level of anus, 0.039 to $0.062(0.051)$. Cephalic inflation 0.099 to 0.113 long by 0.065 to 0.081 . Excretory pore 0.339 to $0.449(0.387)$ and nerve ring 0.206 to $0.243(0.221)$ from anterior extremity. Distance from nerve ring to excretory pore 0.130 to $0.206(0.169)$. Cuticle provided ventrally with 12 longitudinal ridges decreasing in height dorsad. Oesophagus 0.664 to $0.714(0.694)$ long, and 0.055 to $0.079(0.065)$ wide at base. Anus 0.109 to $0.125(0.119)$ anterior to end of tail; tail provided with caudal spine 0.008 to 0.011 long. Vulva 0.478 to 0.522 $(0.506)$ anterior to end of tail (to base of caudal spine). Vagina 0.600 to 0.745 (0.664) long. Ovijector 0.189 to $0.305(0.233)$ long, with anterior chamber averaging 0.070 by 0.057 and posterior chamber averaging 0.163 by 0.086 . Thin-shelled eggs 0.079 to 0.089 by 0.040 to $0.057(0.082$ by 0.046$)$.

TYPE HOST: Heather vole, Phenacomys intermedius Merriam.

TYPE LOCALITY: Hurricane Ridge, Mt. Angelus Trail, Olympic Peninsula, Clallam County, Washington, U.S.A.

HABITAT: Cecum of host.

TYPES: U.S. National Museum Helmintho- logical Collection No. 72664 holotype (male) and allotype; No. 72665 paratype. Paratypes also deposited at Puget Sound Museum of Natural History.

\section{Comparisons}

The genus Heligmosomoides includes 24 species, of which 10 have been recorded in North America (Durette-Desset 1971; Durette-Desset et al. 1972). Two species, H. hudsoni (Cameron, 1937 ) and $H$. polygyrus (Dujardin, 1845), the latter represented in North America by two subspecies, are holarctic in distribution. $H$. johnsoni sp. nov. is probably host specific for Phenacomys, a nearctic genus of rodents, in which it is adapted to conditions provided by the specialized cecum. Consequently, it is compared only with species of Heligmosomoides known from North America.

Eight nearctic species and a subspecies of $H$. polygyrus occur in arvicoline rodents: bullosus Durette-Desset, 1967 (with two subspecies); carolinensis (Dikmans, 1940); hudsoni (Cameron, 1937); longispiculatus (Dikmans, 1940); microti (Kuns and Rausch, 1950); montanus DuretteDesset, 1967; tenorai Durette-Desset, 1967; wis consinensis Durette-Desset, 1967; and polygyrus americanus Durette-Desset, Kinsella, and Forrester, 1972. H. douglasi Durette-Desset et al., 1972 is known only from a cricetid, and $H$. polygyrus bakeri Durette-Desset et al., 1972 occurs in murids and cricetids.

Direct comparisons were made with $H$. hudsoni, from a varying lemming collected by one of us at Point Barrow, Alaska, and with $H$. polygyrus americanus, obtained from a heather vole by Dr. M. L. Johnson. The infected animal was born in captivity from a pregnant female captured in Linn County, Oregon, by Mr. Chris Maser, Puget Sound Museum of Natural History. $H$. johnsoni resembles $H$. hudsoni in lacking cuticular ridges dorsally, in having bursal rays of similar relative lengths, and in the female, in having the vulva situated relatively far anterior to the anus. The male $H$. johnsoni is a smaller nematode, but the spicules are much longer than are those of $H$. hudsoni $(1.4-1.5 \mathrm{~mm})$. It differs

FIGs. 1-6. Heligmosomoides johnsoni sp. nov. Fig. 1. Anterior end of female. Fig. 2. Caudal end of male, dorsal view. Fig. 3. Bursa of male, lateral view. Fig. 4. Genital cone and dorsal ray of male, dorsal view; $e d=$ externodorsal ray. Fig. 5. Caudal end of female, lateral view. Fig. 6. Transverse section of female, twothirds of distance from anterior end, showing arrangement of cuticular ridges. 
from $H$. hudsoni also in form of dorsal ray, in having a relatively longer oesophagus, and in the female, in size of egg $(0.070$ by 0.050 in $H$. hudsoni). H. johnsoni differs from $H$. p. americanus in number and disposition of cuticular ridges, in having much longer spicules $(0.87$ to 0.95 in $H$. p. americanus), in form of dorsal ray, and in the female, in the more anterior position of the vulva.

The absence of cuticular ridges dorsally separates $H$. johnsoni from the remaining species; the dorsal ray of $H$. johnsoni also appears to be distinctive in form. The spicules are distinctly shorter (less than $2 \mathrm{~mm}$ ) in bullosus, carolinensis, and douglasi, and much longer (3.9 $\mathrm{mm}$ or more) in longispiculatus and montanus. The spicules of $H$. johmsoni are similar in length to those of microti, tenorai, and wisconsinensis; it differs from these in having relatively short externodorsal rays, and in proportions of other structures. The female $H$. johnsoni is further distinguished by the more anterior location of the vulva, the relative proportions of other structures, and in some cases by size of egg.

Dr. M. L. Johnson first observed that $H$. johnsoni produces distinctive lesions in the cecum of the host, as does H. hudsoni in Dicrostonyx. These lesions will be described elsewhere.

\section{Discussion}

Heligmosomoides hudsoni and $H$. johnsoni, inhabiting the cecum of Dicrostonyx spp. and Phenacomys intermedius, respectively, have in common, morphological characteristics that distinguish them from the remaining species of Heligmosomoides. The morphological similarities are probably a result of convergent evolution in two species that have become adapted to the unique biotope provided by the specialized cecum of the hosts. Dicrostonyx is considered to be the most primitive of the lemmings and, on morphological grounds, one of the most isolated of the genera in Arvicolinae (Hinton 1926). Of palaearctic origin, Dicrostonyx appears to have become established in North America during early Rancholabrean (preWürm) time (Repenning 1967). Phenacomys is a nearctic genus that can be traced to the late Pliocene (Simpson 1945). The genera in Arvicolinae are considered at the present time to be polyphyletic (Repenning 1968).

Durette-Desset et al. (1972) have postulated a dual origin for species of Heligmosomoides in
North America. According to their hypothesis, most nearctic species arose after the introduction of ancestral forms as a result of faunal interchanges during Pleistocene time. A second group, consisting of the two subspecies of $H$. polygyrus, differentiated from populaticns in house mice, Mus musculus L., introduced from Europe during the period of colonization of North America. Zoogeographic evidence indicates that $H$. hudsoni entered North America with the precursor of the Recent forms of Dicrostonyx not later than the penultimate glacial period (early Rancholabrean time) (Rausch and Rausch 1972). H. johnsoni may be of comparably ancient origin, or it possibly is derived from $H$. hudsoni, having adapted to Phenacomys after populations of Dicrostonyx were displaced southward by the Würm glaciation. Remains of both Dicrostonyx and Phenacomys have been found in late Pleistocene deposits in Pennsylvania (Guilday and Doutt 1961).

The origin and taxonomic status of $H$. polygyrus americanus appear to be more obscure. This nematode has been recorded in Oregon and Montana by Durette-Desset et al. (1972). Schad (1954) reported Nematospiroides dubius Baylis, 1926 (=H. polygyrus) from a vole, Microtus chrotorrhinus (Miller), from the Province of Quebec, in eastern Canada. It was subsequently determined by Peterson (1962) that the host was instead Phenacomys ungava Merriam $(=P$. intermedius celatus Merriam). From the study of Schad's material, Durette-Desset et al. (1972) concluded that the species was $H$. p. americanus. This nematode thus appears to occur in $P$. intermedius throughout its geographic range. Since it must be assumed that adaptation to Phenacomys would have involved a single population of $H$. polygyrus, it does not seem possible that this nematode could have attained its extensive geographic distribution within the period of time specified by Durette-Desset et al. (1972). The problem is complicated also in that some subspecies of $P$. intermedius have disjunct ranges in mountainous regions of western North America. The occurrence of $H$. p. americanus in such isolated populations (e.g., the Olympic Mountains of western Washington) would support the hypothesis that this nematode was a widely distributed parasite of $P$. intermedius before the range of this rodent was modified by events of the last glacial period. Further investigation may 
show that $H . p$. americamus is a distinct species restricted in occurrence to Phenacomys.

\section{Acknowledgments}

We thank Dr. Murray L. Johnson for the opportunity to study these nematodes, and $\mathrm{Mr}$. Gerald C. Kelley, Arctic Health Research Center, for photographic assistance.

Durette-Desset, M.-C. 1971. Essai de classification des nématodes héligmosomes. Corrélations avec la paléobiogéographie des hôtes. Mém. Mus. Nat. Hist. Nat Paris, Sér. A. Zool. 69: 1-126.

Durette-Desset, M.-C., J. M. Kinsella, and D. J. Forrester, 1972. Arguments en faveur de la double origine des nématodes néarctiques du genre Heligmo somoides Hall, 1916. Ann. Parasitol. Hum. Comp. 47 $365-382$.

Guilday, J. E., and J. K. DoutT. 1961. The collared lemming (Dicrostonyx) from the Pennsylvania Pleistocene. Proc. Biol. Soc. Wash, 74: 249-250.

Hinton, M. A. 1926. Monograph of the voles and lemmings (Microtinae) living and extinct. Vol. 1. Br. Mus. (Nat. Hist.), Lond.

Peterson, R. L. 1962. Notes on the distribution of Microtus chrotorrhinus. J. Mammal. 43: 420.

RaUsCH, R. L., and V. R. RausCH. 1972. Observations on chromosomes of Dicrostony $x$ torquatus stevensoni Nelson and chromosomal diversity in varying lemmings. Z. Säugetierk. 37: 372-384.

REPENNING, C. A. 1967. Palearctic-nearctic mammalian dispersal in the late Cenozoic. In The Bering land bridge. Edited by D. M. Hopkins. Stanford University Press, Stanford, California.

- 1968. Mandibular musculature and the origin of the subfamily Arvicolinae (Rodentia). Acta Zool. Cracov. 13: 29-72.

SCHAD, G. A. 1954. Helminth parasites of mice in northeastern Quebec and the coast of Labrador. Can. J. Zool. 32: 215-224.

Simpson, G. G. 1945. The principles of classification and a classification of mammals. Bull. Am. Mus. Nat. Hist. 85: $1-350$ 